\title{
The Sustainable Management of Privately-Owned US Forests
}

\author{
Edward L Kick ${ }^{1 *}$, Jonathan E May ${ }^{2}$, David K Schnake ${ }^{3}$ and Gretchen Thomson ${ }^{4}$ \\ ${ }^{1}$ Department of Agriculture and Resource Economics, North Carolina State University, USA \\ ${ }^{2}$ Campbellsville University, USA \\ ${ }^{3}$ NCDA\&CS Research Stations Division, USA
}

${ }^{4}$ Family Health International 360, USA

Submission: February 06, 2017; Published: February 20, 2017

"Corresponding author: Edward L Kick, Department of Agriculture and Resource Economics, North Carolina State University, 3324 Nelson Hall, 2801 Founders Drive, Raleigh, NC 27695, USA, Email: elkick@ncsu.edu

\begin{abstract}
We investigate a number of the causal mechanisms behind the participation of private forest owners in the commercially sustainable management of their forests. With data from the National Woodlands Owners Survey, we use a synthesis of themes from two sociological perspectives, the "capitals" and spatial inequality approaches, as our point of theoretical departure. We validate a package of hypotheses drawn from these approaches and other literatures, which emphasize key sets of socio-demographic characteristics of owners, with a hierarchical linear modeling methodology. We also provide a related agenda for future research and for policy interventions. Among these is forestry education programs that produce graduates killed in reaching underserved audiences, as well as sensitivity to the cultural legacies in different regions of the country.
\end{abstract}

Keywords: Private forest ownership; Sustainable management; Capitals; Spatial inequality, Underserved audiences; Cultural legacies

\section{Introduction}

Forests have immeasurable value to humans in providing basic aesthetic satisfaction, shelter from the sun, moderation of air temperature and traffic noise, the conservation of water, aid in the fight against soil erosion, reduction in runoff, prevention of flooding, the sequestering of carbon, absorption of a range of other toxins, and provision of an ever-increasing bounty of pharmaceuticals. At the same time they serve as essential sources for warmth and housing for humans and niches for our co-species, while ensuring the biodiversity of the planet.

Commercially, forests are crucial to construction of national infrastructures to the provision of commercial and household furnishings worldwide, while sustaining the world's evergrowing demand for paper products. In fact, the wood industry accounted for around 3\% of the total employment and GDP of the United States in the year 2010 USDA Forest Service [1]. It is noteworthy then, that at the turn of this century one-third of the land area in the US that could be forested or reforested (about 302,000,000 hectares) was being used for other endeavors USDA Forest Service [2].This has been especially true in the Eastern U.S.
Privately-owned forest lands offer economic opportunities for owners. Indeed, over a decade ago available data on the US forest and paper industry's use of trees suggest it is the largest in the world, contributing $\$ 230$ billion in sales annually to the US economy alone USDA Forest Service [1]. Yet, in the U.S. only one in five acres of family forest land is owned by someone with a written forest plan Butler $[3,4]$. The absence of a management plan and ownership itself results from a set of common socioeconomic, demographic and spatial dynamics. Unfortunately, while the literature on forests is immense, there are far fewer treatments of private forest owners and their management plans. Even then, those less frequent studies commonly center on singular causes of forest management such as economic incentives and do not provide the broader social interpretations needed to theoretically link the many demonstrated or plausible correlates of privately-owned forest management.

In the present treatment we use a multiple capitals perspective e.g. Flora et al. [5] combined with a spatial inequality view of society in general e.g. Lobao \& Saenz [6] to provide a synthesized theoretical understanding of forest ownership 
behaviors that reflect socio-demographics and differentiate ownership characteristics by space and place. We concede at the onset that we are unable to synthesize the overwhelmingly large number of factors that may affect forest owners' forest management decisions into a single meaningful theory. Analysis possibilities are further limited due to the absence of national data on a range of possible causes, including those related to economics and aspects of technology. Nonetheless we offer and test an integrative theoretical perspective of forest management that brings together the socio-demographic and spatial characteristics of owners, which dominate in the Woodlands Study data.

\section{Social science research and theory on sustainable forestry management}

For some time the literature on forest ownership and utilization was dominated by descriptive rather than causal treatments. Quite a bit is known about the characteristics of forests in the U.S., as well as the diversity of forest owners, including non-industrial privately- owned forests (NIPF) and the substantial differences in their forest-use practices Max \& Lehman [7]; Mehmood \& Zhang [8]; Schelhas et al. [9]. It is true that most family forest owners do not plan to do much with their forestland in the next five years Butler [6]. However, empirical work in recent years has more carefully heeded the call by Bliss \& Martin [10] for better understanding of the ownership and management practices of NIPF owners. These are all the more crucial given that the behaviors of NIPF landowners in the past have not always been sustainable, and they are not likely to be in the future without appropriate interventions. This is consequential for forests in their own right, but also for all of the central environmental, economic and social outputs of forests, as outlined above.

Part of this problem stems from creating parcels in forests. In stark contrast to agricultural land which has tended to become accumulated into larger holdings over the past century, forest land in the United States has been cut into smaller and smaller parcels Kittredge [11]; Mehmood \& Zhang [12]; Moldenhauer \& Bolding [13]. As the forest is parceled into smaller and smaller segments the likelihood that the owners of these forests will spend the time and energy to manage their forests decreases, partly because the per-acre costs of management increases Kittredge [11]; Moldenhauer \& Bolding [13]. There is some evidence that elements of the forest industry have adapted to the increasingly small ownerships at least in the purchasing and cutting of timber Rickenbach \& Steele [14], but that does not necessarily lead to sustainable management. Smaller plots generally result in reduced forest management.

Unfortunately, we cannot test a number of the plausible correlates of sustainable forest management, because these correlates are not represented in the data set used, the National Woodland Owners Survey (NWOS). For example, the exact methods for creating parcels of forest acreage likely influence utilization practices are of interest, but these methods have not been measured in the data. Further, studies have linked forest utilization to market- and price-related forces Adams et al. [15]; Alig et al. [16]; Beach et al. [17] that are not measured in the data. As well, the importance ofeconomic incentives such as tax relief and subsidies, which have been examined by others, are not part of the NWOS data set Kluender et al. [18]; Brokett et al. [19].

However, the NWOS data are rich in many other respects and we are able to address another large body of literature that often links a range of individual socio-demographic characteristics of NIPF owners to their management decisions. These characteristics include wealth Bullard et al. [20], age, education Creighton et al. [21], and gender Warren [22], among others. In a related vein, a number of studies conclude that the better communication of information by forest maintenance experts to owners holds the key to influencing forest owners to manage their forests in optimal ways Baldwin \& Haymond [23]; Kittredge et al. [24]. Unfortunately these possible causal factors rarely are empirically treated together, especially as companion hypotheses, particularly with the many other reasonable hypotheses about the correlates of private forest management. It is in principle possible that individual factors are simply highly correlated with one another and only by these proxy associations are they related to private forest management activities. However, consider that although the data are somewhat dated, men have occupied $76 \%$ of all STEM jobs in the U.S. while women hold $24 \%$ of these technology-related occupations American Community Survey 2009. These are hardly coincidental, and help to explain well-being differences between them. Nevertheless, we attempt to overcome the ambiguity of correlation vs. causation by using a multivariate technique that simultaneously controls for many specified causes, eliminating spurious "causes" of the dependent variable, while allowing us to take advantage of the linear and additional nature of regression analysis.

Whether it is sustainable management in general, or specifically owners' management of the forests they own, a successful synthesis of the voluminous explanatory hypotheses in the literature is impossible in the space of this paper. However, the more tractable goal of weaving major themes in a tenable way that could result in research results that improve forest owners' practices is an attainable goal. With that in mind, of particular importance to our discussion are some of the primary personal correlates of successful management, especially as they operate in certain macro regions or spaces of the U.S. With respect to policy implementations we emphasize the flow of sustainable, management-related information and resource access for groups that often are removed from the center of key information. In tandem with this, we emphasize the personal correlates of owners that in contrast appear to be directly related to that information flow.

As one introductory illustration, Warren [22] points to the generally disadvantaged role of women who "go it alone" 
in agricultural endeavors. Put another way, they do not have a number of the multiple "capitals" or advantaged sociodemographic characteristics as articulated by Flora et al. [5] and introduced above. In fact, the role of women in forestry has been examined extensively in developing countries as disparate as Nepal Agarwal [25], Hartter [26], and Voeks [27]. Unfortunately, there is an overall lack of comparable examinations of the role of women in sustainable forestry management in the United States Warren [22]. Women, in those U.S. studies, tend to think of and treat forests somewhat differently than men, and women have been found to have on balance somewhat different views than men concerning environmental issues and natural resources in general Tindall et al. [28]; Ozanne et al. [29]; Smith et al. [30]. Despite these ideological differences, which might in fact make women more likely to think about sustainability or environmental over short-term financial gain, women may face greater challenges in managing their forests due to the lack of integration into extension networks that provide to others the needed forestry management information Warren [22].

Many of the other correlates of less successful private forest management could reasonably follow the same logic (e.g., reduced technological capacity and capitals such as wealth, size of holding, race and ethnicity, education, elderly standing). While there are ideological differences that may differentiate owners based on these factors, access to and exclusion from resources or capitals likely play a significant part in the differential management of diverse groups of owners.

\section{Theoretical frameworks}

In advance of our findings we offer a preliminary interpretation of private owners and their sustainable forest management practices. We rely on two theoretical perspectives to aid in our interpretation. The first is the multiple capitals perspective in which human circumstances, social characteristics, and environmental factors are all seen as "capitals" that can be used to create economic (and other non-economic, yet valued) returns. We complement that theory with the "spatial inequality' perspective, which sees unequal access to resources (i.e. capital in all of its forms) as related to geographical space and place Lobao \& Saenz [31]. These harmonious perspectives shed new light in an area more typically dominated by studies using economic or ideological themes. We do, however, treat these latter themes in our conclusions.

That a variety of dynamics other than finances can be seen as capital to be invested to enhance a range of returns is a venerable approach, beginning with the understanding from economics that the abilities, training, and education of people can be thought of as human capital. Kiker [32] dates the earliest use of the concept (although not the term) to 1691 and argues that the idea was in common use by the mid-1800s. Social capital was more recently considered by sociologists such as Coleman \& James [33], Putnam [34], although what constitutes social capital precisely has been widely debated Fulkerson et al. [35]. Perhaps the most developed capitals approach is the community capitals perspective advanced by Flora [5]. Their model includes seven distinct types of capital: built, financial, political, social, human, cultural, and natural. Their model specifically relates these capitals to their availability to communities and community members and considers how these actors can use the capitals to achieve a range of outcomes, whether they be economic or noneconomic in nature. We utilize their framework to understand the management practices of private forest owners, recognizing that each owner is embedded in a multidimensional milieu that drives his or her use of capitals towards specific forest outcomes.

Within Flora and Flora's approach already is the idea that the place characteristics of a community augment or diminish the availability of other capitals. While our data do not enable us to analyze community-level factors, they do allow us to analyze spatial characteristics associated given forest owners, such as the size of the owner's forest holdings and the region of the country in which an owner lives. In order to suggest how these spatial differences in access to capital (in all its forms) and spatial differences in them may be related to other factors that influence key differences between owners such as wealth, we rely upon the spatial inequality perspective.

Spatial inequality is a broad theoretical perspective that attempts to expand stratification research to include space and place, particularly by emphasizing how place characteristics intersect with other dimensions of (disadvantage (e.g., in a neighborhood, within a community, in urban v. rural space, or within a particular region of the United States).Spatial inequality theories include perspectives as diverse as Wilson's [36,37] theory on the urban inner city, Wimberley \& Morris's [38] Southern Black Belt research, and Lobao and colleagues' work Lobal [39]; Lobao \& Saenz [31] that hypothesizes rural space is a socioeconomic periphery. The key concern of spatial inequality research is the concern with providing geographic context to stratification processes and outcomes Lobao \& Saenz [31]; Gieryn [40]; Tickamayer [41]. In principle spatial inequality could include differences across space in how regional characteristics (such as regional differences in access to various capitals) foster the sustainable management of forests and the substantial payoff these characteristics yield to owners, communities and entire regions of the U.S. It might even account for international differences. Of course disadvantaged space could also ensure precisely the opposite-the absence of optimal management, and "yields" that relegate space inhabitants to further poverty and the relative absence of personal and collective well-being.

The present study tests hypotheses based on the arguments of the capitals and spatial inequality theorists. Among these are that increased human capital in the form of education (including technical education) impacts forest owners' capabilities to optimize the management of their forests. As Castells [42] observes, "Information technology, and the ability to use it and adapt it, is the crucial factor in generating as accessing wealth, 
power, and knowledge in our time." Spatial inequality theory would argue that increasingly productive teaching and learning, access to cutting-edge mechanicals, and equipping students with higher-order thinking ability leads to competencies in basic information and communication networks, which are more likely to be endemic in the Northern than the Southern states. Reality exacerbates this trend as urban teachers have better access to advance technological (e.g., internet) equipment than their counterparts in rural areas.

Financial capital in the form of income, and natural capital in the form of larger forest holdings, will both result in increased forest management. It is noteworthy that according to Forbes (http:///www.forbes.) that the poorest states from first to last are Mississippi, Arkansas, Tennessee, West Virginia, Louisiana, Montana, South Carolina, Kentucky, Alabama, and North Carolina. Clearly the South is the poorest region in the country and likely to be most deficient in these forms of capital development.

Social capital within our model takes the form of gender, duration of ownership (tenure), residence on the land, and whether or not the land was gained from family or otherwise through inheritance. We hypothesize that duration of ownership, residence on the land, and family origination of the land will have positive impacts on forest management due to longer-term and increasing potential contacts with other forest owners and foresters (i.e. social capital) as well as through the development of a forest ownership legacy (i.e.,a longstanding cultural capital). We further hypothesize that males will manage more efficiently than females due to greater access to forest information, due to their access to others owners and for the other reasons just discussed.

Age within our model represents a decline in human capital (given the mean age is 60 ), and thus the physical and technicallyrelated ability to bring other capitals to bear on forest management. Older age is therefore hypothesized to decrease sustainable management. We recognize this relationship is not perfectly monotonic even if empirically treated as such. Only the very young and more senior will experience human capital limitations as forest managers. Those in between will fall into a different category of capability. However, given the more senior age of our sample the relationship to human capability and successful forest management is easier to predict.

In other words, we hypothesize that individual capitals, of various forms and depending on their state, either contribute to or constrain the sustainable management of privately-owned forests. In addition, while it may not be in a strictly "interaction" way involving the multiplication of unitary capitals, they certainly act in an additive way to enhance or limit forest management.

Relatedly, geographic space is clearly related to these socio-demographic dynamics. For instance, relevant to both approaches, research on regionalized rural poverty has, among other things, examined how class, race, and gender inequality differ across spaces (the Northeastern US vs. the Southern US) and persists within them. Two spaces of particular interest to demographers and spatial theorists have been "the South" Wimberley \& Morris [38]; Reed [43] and rural America in general Duncan [44]; Tickamayer \& Duncan [45]. The relevant data on well-being in these spaces are fairly well known and alarming. Wimberley \& Morris [38] observed over a decade ago that "the South's 13.6 million poor represent a $40 \%$ share of all U.S. poverty." Indeed 2010 census data show that $22 \%$ of the people in the non-metropolitan areas of the South and $15 \%$ of those in metropolitan areas of the South are classified as "poor" USDA Forest Service [1]. Basic rural and urban, as well as regional, distinctions have contributed to understanding how inequality differs across physical spaces Fisher [46]; Mencken [47]; Friedman \& Lichter [48]. Other research has explored the social processes that contribute to these differences. Some researchers attribute these circumstances to natural capital foundations, the financial base, economic restructuring, the relative absence of economic and educational opportunities, and to weaknesses in social support networks Lee et al. [49]; Putnam [34]. Thus, for present purposes, aside from the relatively large percent of land in the South under private forest ownership 86\%, compared with other U.S. regions, many of the other inequalities we center upon are most prominent there too. We turn our empirical attention to them later, although in doing so; we do not lose sight of the breadth of spatial inequalities across the U.S. and the world as a whole.

\section{Materials and Methods}

\section{Sample}

This research uses data from the 2002-2006 National Woodland Owners Survey, conducted by the United States Forest Service (USDA) as part of their Forest Inventory Analysis (see Butler and Leather berry 2004 for more information on these data). The data were collected using spatial sampling techniques so that the probability of being surveyed was directly proportional to the amount of forest land owned, although sufficiently sizable numbers of small forest units were included. There were 16,806 respondents to the survey of which 15,353 were individual or family owners. Due to missing data, our analysis included only 8,411 of these respondents (about 55\%), which were examined as an aggregate to ensure representative ness. Ideally newer data would be used, but they are not yet publicly available

$$
\text { (http://www.fia.fs.fed.us/nwos/results/2016). }
$$

\section{Analytical technique}

The analytic technique used to complement conventional data from experts is hierarchical linear modeling (HLM), also called multi-level modeling. Individual owners were divided into geographic regions in the United States based on the forest regions codified by the USDA Forest Service. An owner was assigned the region in which he or she had the largest forest holdings. Owners with forest holdings spread out across a state were placed in a region together within their state. Regions with 
small numbers of owners were combined with neighboring regions. In the end, 188 geographic regions were created. These regions served as the second level in the two-level HLM model. Only the regional variables South and West were measured at the second-level. West, for this research, is defined as Kansas, Nebraska, the Dakotas, New Mexico, and everything west of those states. The South region includes Virginia, West Virginia, Kentucky and everything directly south of those states, proceeding westward to include Oklahoma and Texas. The Northern region is the omitted or comparison category in the estimation and includes all other states. The HLM technique is more appropriate than the more commonly used ordinary least squares (OLS) technique because two, not one, levels or domains are analyzed-the immediate circumstances of the forest owners and their regional circumstances Garson [50].

\section{Dependent variable}

The dependent variable in this research is an additive index constructed from eleven dichotomous variables. One point was assigned to each respondent for which each of the following applied:

1. Has harvested their forest (ever)

2. Has harvested timber in the past five years

3. Has harvested to sell for saw logs, pulpwood, or veneer

4. Has done site preparation work on the forest land

5. Has planted trees

6. Has done fire hazard reduction

7. Has applied chemicals

8. Has done road maintenance

9. Has set aside land for a wildlife habitat

10. Has a formal management plan and

11. Plans to harvest saw logs in the future.

This index has a Cronbach's alpha of 0.795, indicating a significant degree of necessary correspondence across the items added to form one measure of sustainable management. The strong alpha points to the more typical case across many U.S. ecosystems. Relatedly, this rather robust alpha holds, even though the indicator may not encompass all the criteria that might be selected by an environmental sustainability proponent, or by individuals with strictly commercial interests. Certainly those with strictly environmental sustainability goals might favor items 5 and 9 over others that may reflect instead the focus of solely commercial ventures, or" weak sustainability" positions as articulated by some economists e.g., Neumayer [51]; Solow [52]; Hartwick [53]. Put another way, sustainable management, as used in our analysis, includes environmentally sensitive measures but clearly is more of a commercial and not primarily an environmental measure. We caution readers not to interpret our use of "sustainable management" as reflecting a principal concern with the environment, which it does not.

\section{Independent variables}

The individual-level independent variables in this research are the capitals and other characteristics reflected in age (human capital), education, size of forest holdings, tenure on the land, income (financial capital), family origin, residence, and owner's gender. Age is measured using a 7-category scale (under 25, $25-34,35-44 \ldots 75$ and older); under age 25 is coded as 20,75 and older as 80 , and each of the other categories are coded at their midpoints. Education is coded using a six point scale: less than high school $=1$, high school diploma $=2$, some college $=$ 3 , Associates or technical degree $=4$, Bachelor's degree $=5$ and graduate degree $=6$. Size of forest acres is measured as the total number of forest acres owned. This variable is log-transformed, as were others noted below, to address the normality in distribution assumptions of our analytical technique. Tenure is measured in years owned; tenure claims of longer than 70 years were recorded as 70 years. Income was measured using the following scale: less than $\$ 25,000 ; \$ 25,000-49,000 ; \$ 50,000$ 99,$000 ; \$ 100,000-199,000 ; \$ 200,000$ and up; each category was replaced with its midpoint and measured in $\$ 1,000$ s of dollars except for the lowest category (replaced with $\$ 20,000$ ) and the highest category (replaced with $\$ 200,000$ ). We employed several other strategies for coding income, but they all yielded similar results. Family land is a dichotomous variable coded "1" if the owner indicated that the land was either inherited and/ or obtained from a family member; otherwise, the variable is coded " 0 ". Residence is also is a dichotomous variable coded " 1 " if the owner has a primary or secondary residence on the forested land. The gender of the owner(s) is represented by two "dummy" variables, female and male. Those owners who checked both male and female (representing a pair) are the comparison category of couples. Acres owned is coded in binary fashion (1/0) to distinguish those who owned more than 100 acres or less than 100 acres. Although this coding masks some differences between respondents the distribution of the "acres" variable showed owners in virtually all cases either owned smaller holdings, or very large holdings in excess of the 100acre threshold, suggesting a binary rather than continuous coding should be used. Finally, there were only a trivial number of minority private owners, and as subsequently discussed, the variable "race" therefore could not be included in the analysis.

In using multi-level modeling (HLM) centering of the variables can be useful. In this model, the numerical variables (age, education, forest acres, tenure, and income) have all been centered on their grand mean. This strategy was not employed for the dichotomous variables. We refer those interested in the specifics of HLM, once again, to Garson [54].

Random effects were added to age and forest acres because preliminary models revealed a strong likelihood that these variables would have second- level random effects associated 
with them in the final model. Lastly, we created an interaction term between South and income and South and total forest acres owned to test for the compounded impact of these economic indicators (income and wealth) across regions, and especially in the South Wimberley \& Morris [38]; Warren [22]. Originally, we used dummy variables to differentiate North, South, and West. However, in all models we found that differences between North and West were not significant. In each case, differences between the South and the North and West as a set were most important. Thus, for the sake of clarity, the extra variables were removed.

\section{Results and Discussion}

Tables 1 and 2 present the descriptive statistics and bi variate correlations for all variables included in our model. We include them so that readers may reproduce our results and understand the composition of the sample. The mean age of respondents in the sample is approximately 60 years old. The average level of education for participants in our sample shows some college experience. The average income is estimated as $\$ 67,500$. Average natural log of forest acres is 4.47 (or unlogged, 87.4 acres). Just under half $(44 \%)$ of those in the sample received their forests through inheritance or from a family member. Over $84 \%$ of those

Table 1: Means, Standard Deviations, Sample size.

\begin{tabular}{|c|c|c|c|}
\hline & Mean & Std. Deviation & N \\
\hline Age & 60.5 & 12.391 & 8411 \\
\hline Education & 3.73 & 1.614 & 8411 \\
\hline Total Number of Forest Acres (ln) & 4.4691 & 1.65562 & 8411 \\
\hline Number of Years Owned (70 max) & 24.8838 & 14.825 & 8411 \\
\hline Income & 67.5 & 26.2 & 8411 \\
\hline Inherited or Acquired from Family & 0.44 & 0.496 & 8411 \\
\hline Female & 0.1179 & 0.32246 & 8411 \\
\hline Male & 0.84 & 0.36663 & 8411 \\
\hline Resident & 0.7429 & 0.43708 & 8411 \\
\hline
\end{tabular}

Table 2: Bivariate Correlations.

\begin{tabular}{|c|c|c|c|c|c|c|c|c|c|c|}
\hline & 1 & 2 & 3 & 4 & 5 & 6 & 7 & 8 & 9 & 10 \\
\hline Age (1) & 1 & $-.078^{* *}$ & $.121^{* *}$ & $.582^{* *}$ & $-.208^{* *}$ & $.079^{* *}$ & $.054^{* *}$ & $-.055^{* *}$ & $-.061^{* *}$ & $-.024^{*}$ \\
\hline Education (2) & $-.078^{* *}$ & 1 & $.161^{* *}$ & $-.114^{* *}$ & $.428^{* *}$ & 0.018 & $.033^{* *}$ & $-.040^{* *}$ & $-.118^{* *}$ & $.145^{* *}$ \\
\hline $\begin{array}{l}\text { Total Number of Forest Acres } \\
\qquad(\ln )(3)\end{array}$ & $.121^{* *}$ & $.161^{* *}$ & 1 & $.203^{* *}$ & $.287^{* *}$ & $.166^{* *}$ & $-.078^{* *}$ & $.087^{* *}$ & $-.058^{* *}$ & $.499^{* *}$ \\
\hline $\begin{array}{c}\text { Number of Years Owned (70 } \\
\text { max) (4) }\end{array}$ & $.582^{* *}$ & $-.114^{* *}$ & $.203^{* *}$ & 1 & $-.184^{* *}$ & $.160^{* *}$ & 0.002 & -0.006 & $.046^{* *}$ & $.125^{* *}$ \\
\hline Income (5) & $-.208^{* *}$ & $.428^{* *}$ & $.287^{* *}$ & $-.184^{* *}$ & 1 & $-.083^{* *}$ & $-.105^{* *}$ & $.126^{* *}$ & $-.076^{* *}$ & $.189^{* *}$ \\
\hline $\begin{array}{c}\text { Inherited or Acquired from } \\
\text { Family (6) }\end{array}$ & $.079^{* *}$ & 0.018 & $.166^{* *}$ & $.160^{* *}$ & $-.083^{* *}$ & 1 & $.077^{* *}$ & $-.089 * *$ & $-.053^{* *}$ & $.092^{* *}$ \\
\hline Female (7) & $.054^{* *}$ & $.033^{* *}$ & $-.078^{* *}$ & 0.002 & $-.105^{* *}$ & $.077^{* *}$ & 1 & $-.838^{* *}$ & $-.059 * *$ & $-.110^{* *}$ \\
\hline Male (8) & $-.055^{* *}$ & $-.040^{* *}$ & $.087^{* *}$ & -0.006 & $.126^{* *}$ & $-.089 * *$ & $-.838^{* *}$ & 1 & $.052^{* *}$ & $.120^{* *}$ \\
\hline Resident (9) & $-.061^{* *}$ & $-.118^{* *}$ & $-.058^{* *}$ & $.046^{* *}$ & $-.076^{* *}$ & $-.053^{* *}$ & $-.059 * *$ & $.052^{* *}$ & 1 & $.066^{* *}$ \\
\hline Primary DV (10) & $-.024^{*}$ & $.145^{* *}$ & $.499^{* *}$ & $.125^{* *}$ & $.189 * *$ & $.092^{* *}$ & $-.110^{* *}$ & $.120^{* *}$ & $.066^{* *}$ & 1 \\
\hline
\end{tabular}


${ }^{* *}$ Correlation is significant at the 0.01 level (2-tailed). ${ }^{*}$ Correlation is significant at the 0.05 level (2-tailed).

Cases= Listwise $\mathrm{N}=8411$

Table 3: Random Effects Models Predicting Sustainable Management of Forests by Owners.

\begin{tabular}{|c|c|c|c|c|}
\hline Fixed Effects & Model 1 & Model 2 & Model 3 & Model 4 \\
\hline Intercept & $2.72^{* * *}$ & $2.59^{* * *}$ & $2.57^{* * *}$ & $2.53^{* * *}$ \\
\hline South & & $0.32^{*}$ & $0.314^{*}$ & 0.2 \\
\hline Age & $-0.027^{* * *}$ & $-0.027^{* * *}$ & $-0.027^{* * *}$ & $-0.026^{* * *}$ \\
\hline Education & $0.12^{* * *}$ & $0.12^{* * *}$ & $0.11^{* * *}$ & $0.11^{* * *}$ \\
\hline Income $(\$ 1000$ s) & -0.0006 & -0.0006 & -0.0004 & $-0.0021^{* * *}$ \\
\hline Income*South & & & & $0.0024^{*}$ \\
\hline Forest Acres (ln) & $0.72^{* * *}$ & $0.72^{* * *}$ & $0.67^{* * *}$ & $0.54^{* * *}$ \\
\hline Forest Acres (ln)*South & & & & $0.28^{* * *}$ \\
\hline Years Owned & $0.017^{* * *}$ & $0.017^{* * *}$ & $0.017^{* * *}$ & $0.015^{* * *}$ \\
\hline Female Owner & $-0.25^{*}$ & $-0.24 *$ & $-0.24^{*}$ & $-0.22^{*}$ \\
\hline Male Owner & $0.32^{* * *}$ & $0.32^{* * *}$ & $0.33^{* * *}$ & $0.33^{* * *}$ \\
\hline Resident & $0.56^{* * *}$ & $0.57^{* * *}$ & $0.56^{* * *}$ & $0.56^{* * *}$ \\
\hline Family & -0.053 & -0.058 & & \\
\hline Family ( $\leq 100$ acres) & & & $-0.28^{* * *}$ & $-0.25^{* * *}$ \\
\hline Family (>100 acres) & & & $0.23^{* *}$ & $0.16^{*}$ \\
\hline Random Effects & St. Dev./Var. & St. Dev./Var. & St. Dev./Var. & St. Dev./Var. \\
\hline Intercept & $0.80 / 0.65^{* * *}$ & $0.79 / 0.62^{* * *}$ & $0.78 / 0.61^{* * *}$ & $0.66 / 0.44^{* * *}$ \\
\hline Income & & & & $0.0016 / 0.00$ \\
\hline Forest Acres (ln) & & & & $0.23 / 0.05^{* * *}$ \\
\hline Individual Level R & $2.11 / 4.46$ & $2.11 / 4.46$ & $2.11 / 4.45$ & $2.07 / 4.27$ \\
\hline
\end{tabular}

Table 3 presents the HLM results. Model 1 is the foundational model. Model 2 adds the South as a regional variable based on earlier arguments, while Model 3 at the bottom of the table divides the effect of a holding being family land into small and large holdings. Model 4 adds the interactions between: income and whether a holding is in the South or elsewhere; and the effect of size of holdings in the South or elsewhere. The use of these two interaction terms is to further identify whether the components of the Southern space make it somewhat unique in those spatial couplings that may impact sustainable forest management practices.

An examination of the fixed effects for Southern region compared to others, our level two or structural/grouping measure, in Model $2\left(0.32^{* * *}\right)$ and Model $3\left(0.314^{* * *}\right)$, seems to show that NIPFs in the South are more likely to sustainably manage their forests than those residing in the Northern and Western regions. We think it interesting that Butler (2008:1) reports only about $20 \%$ of family forest owners have a written management plan. Yet sustainable management varies spatially across the nation. More concretely, however, it would appear that NIPFs in the South as a whole are more likely to conduct sustainable management activities, such as setting aside wildlife habitat, harvesting their forests, planting trees, or mitigating wildfire hazards. This would appear at first glance to run counter to the multiple capitals and related spatial inequalities approaches. Yet, when the effects of Southern space are coupled with income and then forest size (Forest Acres), model estimation (Model 4) shows the fixed, generic spatial impact of the South is no longer statistically significant (.20). We find instead that the size of holdings and the income of owners have different effects within the South than they do in the rest of the country. The effect of holding size is nearly double in the South of what it is in the rest of the country ( 0.54 compared to 0.28 ). We mention in passing that $53 \%$ of the privately-owned forest land in the U.S. is owned by families with over 100 acres in their natural capital (i.e., forest) portfolio Butler [54].

The effect of income, which had been negligible in previous models becomes significant and negative outside of the South 
$(-0.0021)$, but positive in the South. We are reluctant to overinterpret these differences but suspect they may capture the greater commercial interests among wealthier Southerners and the aesthetic and other interests of Northerners Butler [54] (Table 3).

Models 1 and 2 show as well there is no significant impact of family origination ("family") on management practices. However, when the effect is divided between large landowners and small land owners, family is significantly positive for the large landowners and negative for small owners. This suggests that heritage ownership works in two very different ways, and it appears the data represent two very different types of owners: those owners who are interested in honoring heritage by preserving the land in more "pristine" condition (typically owners of smaller plots) and those interested in participating in a family tradition of managing their forests for commercial purposes (typically large plot owners who may find their natural capital holdings lead to greater capital holdings in other sectors).

This difference may highlight the concern woodland experts express over smaller owners, particularly over "parcelization," the increasing division of land into smaller and smaller plots often due to multiple heirs Kittredge [24]; Mehmood \& Zhang [12]; Moldenhauer \& Bolding [13]. In this case, it appears that family attachment to these plots creates a disincentive to management in addition to the disincentive that smaller property size already creates.

Other indicators in the model that are correlated with our sustainable management index at a statistical significance level of .05 or better across all models include age and education. Thus, more highly educated and younger men, both with greater human capital, are most likely to sustainably manage their forests. Older owners, though numerically significant, are physically disadvantaged in caring for their forests. However, younger and more highly educated owners have both the energy and technical knowledge, or human capital, which serve as solid foundations for their efforts to be sustainable managers. These are expected results found in the various other studies treated above. However, here we find it as part of a package of capitals, providing a broader and theoretically interpretable understanding of the relationships discovered. Other studies have identified age, education or other factors such as whiteness and wealth as individually associated in some way with forest ownership Butler [54] However, for the most part they have not advanced a "package" of such characteristics that affect sustainable management in theoretically interpretable ways, which are estimated by appropriately suited techniques used when multiple "nests" or domains of variables are used. The domains are capitals that capture overall capability, or what many would consider relative power, and the ability to translate the interrelated dimensions of their capital-based power into favorable sustainability activities, leading to greater commercial success, and subsequently greater capital power for them and often for their offspring.

We would like to make note of one other finding, that of the effect of gender. Female ownership has a significant negative effect on sustainable management behaviors. Net of all other effects, male-only owners had significantly higher management scores (0.33 points) than male-female owners (presumably couples or groups consisting of both male and female owners) who had significantly higher scores ( 0.22 points) than femaleonly owners. Again, the capitals interpretation is relevant. The sociological literature historically has placed emphasis on "capital" power differences between men and women, which arguably may emerge differentially in spatial divisions of the country, as other nested capitals do.

\section{Conclusions}

A number of our individual findings are consistent with a wide range of earlier efforts, Woodland's study findings, or could in principle be interpreted individually, on an ad hoc basis, with a large variety of approaches. However, the multiple capitals and spatial inequality approaches when taken together advantage the interpretation of sustainable forest management in a unique way. As Coleman \& James [33] points out well, one form of capital can be used to leverage another form of capital. Thus, rather than individual factors working separately, these capitals coupled with spatial dynamics may be viewed as an interlinking, synergistic package that works toward a common end. Part of that end is the provision of sustainable forest management advice delivered to and taken by those who typically are better endowed across a number of socio-demographic and spatial characteristics than are others.

Economies of scale are an important issue in the South and elsewhere in the U.S. Privilege in ownership associated with spatial divisions brings with it a range of other related capital benefits. The advantages of any number of these with respect to sustainable management and capital advancement in multiple areas are both self-evident and heritable across generations. The spatial packaging of these capitals is a major contribution of the present work. We wish to emphasize again that capital characteristics bring with them information critical to sustainable forest management Baldwin \& Hayman [23]; Kittredge et al. [11]. The clear policy implication is that to maximize the utilization of privately-owned forest land in the South, and quite probably in the U.S. as well, it will be necessary for foresters to network energetically with smaller acreage and less privileged forest owners, those in disadvantaged areas, and those with disadvantaged family characteristics Zhang et al. [55]. In making this statement we recognize that foresters and extension personnel have constraints on their time and services that make it difficult for them to reach all prospective clientele. This is true particularly in the more remote areas of the U.S. and, again, especially, in the South, with its geographical limitations, 
ranging from mountains to swampland. We also recognize that issues of trust in some ways generalize to the entire country and are not easy to overcome. Unfortunately issues of trust still separate major groupings in our country.

Critics may see a higher degree of political-economic dynamics in these findings, and may suggest that there is a significant degree of intention behind them. Put another way, as spatial inequality theorists might very well contend, the roles of foresters are structured to serve certain types or "classes" of owners more so than others. We are unable to validate or refute their arguments with the data gathered in this study. However, our findings do show that the personal characteristics of certain owners (e.g., education, income in the South, family inheritance of land, maleness), correlate as a cluster with the ownership of large parcels of space with valuable natural resources ("the forest plantation") that predict to better performance as sustainable forest managers and, we assume, will help ensure into the future even more positive life chances for them and their off spring.

While we consider these findings as important contributions, we recognize that there are other important dynamics that merit consideration. There are factors that we admit we do not address as well as we would like to, and relatedly, we hope for future data and subsequent analyses to do so. For instance, in the case of gender, males as predicted manage with more effectiveness than females. This finding supports our assertion that males have greater social capital through easier access to foresters and other agents. We in addition see that male/female owners have higher levels of management than female- only owners, but lower levels than male-only owners.

This result appears to confirm our approach emphasizing the intersecting capitals and power discussed above. However, we acknowledge another way in which at least one capital can be manifest and affect sustainability that has been suggested by a variety of authors in different contexts e.g. Tindallet al. [28]; Ozanne [29]; and Smith et al. [30]. While it does not address cross-capital connections, it has been argued women in general may think and act somewhat differently with respect to a number of dynamics, including natural resources, than men do. Their joint decisions as owners of forests appear to further reinforce this interpretation. We suggest that this finding may point to a very different kind of "cultural capital" than we have emphasized up to this point in our treatment.

Cultural capital often is linked to an ability to move in certain circles, particularly knowing the etiquette, conversational topics, and experiences that would enable one to mingle among the advantaged classes Bordieu [56]. This relates to dimension of power we have emphasized thus far. This is a limited use of the concept of culture, and we suggest expanding that definition to include all cultural factors (e.g. language, ideology, experiences) that may enable two or more people or groups to relate to each other. In our analysis, having a pro-management ideology would be seen as cultural capital. But the argument has been advanced than females; more generally, may be more likely to have a pro-environment approach. Thus, knowing and having access to foresters and extension agents is social capital, but sharing in the same management ideology as those agents would also be cultural capital. Arguably, formal training in sustainable forestry management may not ensure the inculcation of the proenvironmental approach as adopted by females, when compared to the more nearly commercial approach of males. We emphasize this is not part of our interpretive framework, but it is worth further directed inquiry not now possible with the Woodlands' data.

There is at least one other interpretation worthy of consideration, which plausibly identifies the differences in cultural capital implied in our results. Family of origination (what some forest researchers refer to as "legacy" ownership) serves as somewhat of a force-multiplier with regard to sustainable management practices. For those with larger plots, it increases their management potential, presumably through bringing to bear social and human capital that has accumulated through the generations. For those with smaller plots, legacy status works against sustainable management. This implies that legacy has a different cultural meaning depending on social context. Perhaps we are looking at two groups of owners independent of gender considerations. For one group legacy houses the meaning of "sustainably manage" while for the other legacy means "maintain in a more environmentally pristine state". With these owners, as with female owners, foresters and extension agents intent on bringing these lands under management may need to recognize that there may be a cultural (i.e. ideological) divide to consider. This divide coincides with commercial versus environmental improvement ends. While our information is anecdotal and not even considered in the Woodlands dataset, ideological divides may be an important component in the formal training many foresters and agents receive.

An anomaly is striking in our findings. Outside the South income is negatively related to sustainable private forest ownership. In the South larger forest holdings yield higher levels of sustainable management, which is compatible with the theme that large capital owning runs parallel with commercial uses of the forest land. Yet, it seems that outside of the South, having high income is negatively correlated with sustainable management practices, net of all other factors. According to Examination of the Woodlands' data, 75\% of Northern owners own less than twenty forest acres and they use them primarily for "aesthetics," part of the family home, recreation, family legacy, or as part of a farm. Larger forest holdings, on the other hand, yield higher levels of sustainable management. It would seem, however, that a segment of owners with high levels of financial capital are less inclined to manage their forests unless that capital is tied up in forested land. While we invite subsequent research to address this finding, we note that it at least appears possible that owners 
with lower incomes who do have forest holdings are more likely to think of their forests as potential capital investments, and they therefore manage them more actively. Even less abundant holdings are a natural capital hedge against economic collapse during the modern period of financial capital uncertainty [57].

The divergences seen within the South offer an interesting adjunct to this interpretation. It appears that in the South ownership behaviors follow a more clearly utility maximizing pattern. Size of holdings has a greater impact on sustainable management behavior. This suggests that the divide between small plot owners and larger owners is also larger within the South, which reflects the spatial inequality between regions in the U.S. As has been noted previously, social and economic inequalities are greater within the South.

Beyond this issue, there are several plausibly important factors that we could not consider in this study due to the absence of relevant data in the Woodlands dataset. For instance, unfortunately our data base again does not house more nuanced information on the role of economics and economic policies in sustainable, privately-owned forest management. In addition, it is clear that state incentives and other policies affect management practices in a variety of ways and at different times. Taxation is a critical issue and likely applies especially to "plantations" that are rich in acreage. Taxes are only one important economic factor, however, and there are a host of others that have been or should be investigated in subsequent efforts treating a fuller range of economic and non-economic indicators. As an illustration, the state of Virginia apparently requires that seed trees be spared from cutting, or that regenerating sites must contain a certain percentage of pine. Other examples include rules about required reforestation and the treatment of watersheds. A related concern is whether these instances are sub-optimal when compared to sustainable methods of controlled natural regeneration; that is, the less artificial mechanisms of natural regeneration keep nature and site-adapted genetics on site, which can lessen the impacts of some forest health issues. As well, it often results in the development of at least a partially mixed forest stand that has its own set of benefits. While a rare approach, future research may unveil the potential of this sort of holistic treatment in agents' provision of information to privately-owned forest managers to enhance the sustainability of their forests and land.

Despite some acknowledged areas that either are open to alternative interpretations or require future studies that are more comprehensive, including comparative examinations of other spaces on the globe, we emphasize we have otherwise considered a relatively coherent range of packaged sociological, socio-economic, demographic and ecological dynamics that should further inform the sustainable forestry literature. Sustainable forestry in theory and practice is a complex interplay of these antecedents with a set of other spatial and temporal inequalities in power and well-being that intimately affect the sustainability of natural capita, which is an important part of the more generic form which Flora [5] persuasively emphasize is the foundation for all other capitals (e.g., human, social, built, financial, political and cultural). The many roles of forests, including those unexamined here (e.g., the home it provides for our co-species; carbon uptake; the many consequences of photosynthesis, and immediately or over longer-time periods, the production of multiple energy sources) demand concerted attention. This is even truer in a world characterized by what many see as a dramatically increasing global population coupled with a non-sustainable trajectory in natural capital that threatens humans and our co-species alike.

\section{References}

1. USDA Forest Service (2014) U.S. Forest Resource Facts and Historical Trends. Washington, USA.

2. USDA Forest Service (2004) USDA Forest Service Fiscal Year 2004 President's Budget. Washington, USA.

3. Butler, Brett J (2010) State Foresters by the Numbers: Data and Analysis from the 2008 NASF State Forestry Statistics Survey. National Association of State Foresters, Washington, USA.

4. Butler, Brett J, Earl C (2004) Leather berry America's Family Forest Owners. Journal of Forestry 102(7): 4-14.

5. Flora Cornelia B, Jan L, Flora (2013) Rural Communities: Legacy + Change. ( $4^{\text {th }}$ edn), Boulder, CO: Westview, USA.

6. Lobao L, Rogelio Saenz (2002) Spatial Inequality and Diversity as an Emerging Research Area. Rural Sociology 67(4): 497-513.

7. Max W, Lehman DE (1988) A Behavioral Model of Timber Supply. Journal of Environmental Economics and Management 15(1): 71-86.

8. Mehmood Sayeed R, Daowei Zhang (2001) Forest Parcelization in the United States: A Study of Contributing Factors. Journal of Forestry 99(4): 30 .

9. John S, Zabawa R, Molnar J (2003) New Opportunities for Social Research on Forest Landowners in the South. Southern Rural Sociology 19(2): 60-69.

10. Bliss JC, Martin AJ (1988) Identity and Private Forest Management. Society and Natural Resources 1(1): 365-376.

11. Kittredge, David B (2004) Extension/Outreach Implications for America's Family Forest Owners. Journal of Forestry 102(7): 15-18.

12. Mehmood, Sayeed R, Daowei Zhang (2002) Causes for Continuation of Stable Cost-share Progress for Non-industrial Private Forest Land Owners. Southern Journal of Applied Forestry 48(3): 471-478.

13. Moldenhauer, Matthew C, Chad Bolding M (2009) Parcelization of South Carolina's Private Forestland: Loggers' Reactions to a Growing Threat. Forest Products Journal 59(6): 37-43.

14. Rickenbach, Mark, Thomas W Steele (2006) Logging Firms, Nonindustrial Private Forests, and Forest Parcelization: Evidence of Firm Specialization and its Impact on Sustainable Timber Supply. Canadian Journal of Forest Research 36(1): 186-194.

15. Adams DM, Alig RJ, McCarl BA, Callaway JM, Winnett SM (1996) The Forest and Agricultural Sector Optimization Model: Model Structure and Applications. USDA Forest Service, USA, p. 1-68.

16. Alig RS, Adams DM, McCall BA, Ince PJ (2000) Economic Potential of Short-rotation Woody Crops on Agricultural Land for Pulp Filter Production in the United States. Forest Product Journal 50(5): 67-74.

17. Beach RH, Pattanayak SK, Yang JC, Murray BC, Abt RC (2005) Econometric Studies of Non-industrial Private Forest Management: A Review and Synthesis. Foreign Policy and Economics 7(3): 261-281. 
18. Kluender RA, Walkingstick TL, Pickett JC (1999) The Use of Forestry Incentives by Nonindustrial Forest Landowner Groups: Is it Time For a Reassessment of Where We Spend Our Tax Dollars? Natural Resources Journal 39(4): 799-818.

19. Brokett Charles, Robert Gottfried, Jonathan Evans (2003) The Uses of State Tax Incentives to Promote Forest Preservation on Private Lands in Tennessee: An Evaluation of Their Equity and Effectiveness Impacts. Politics and Policy 31(2): 252-281.

20. Bullard SH, Gunter JE, Dolittle ML, Arano KG (2002) Discount Rates for Nonindustrial Private Forest Landowners in Mississippi: How High a Hurdle? Southern Journal of Applied Forestry 26(26): 26-31.

21. Creighton JH, Baumgarten DM, Blatner KA (2002) Ecosystem Management and Non-industrial Private Forest Landowners in Washington State, USA. Small-scale Forest Economics Management and Policy 1(1): 55-69.

22. Warren, Sarah (2003) One Step Further: Women's Access to and Control Over Farm and Forest Resources in the U.S. South. Southern Rural Sociology 19(2): 94-112.

23. Baldwin SB, Haymond JL (1994) A System Approach to Communication Behavior Among Scientists, Foresters, and NIPF Landowners. Southern Journal of Applied Forestry 18(4): 175-180.

24. Kittredge DB, Finley AO, Foster DR (2003) Timber Harvesting as Ongoing Disturbance in a Landscape of Diverse Ownership. Forest Ecology and Management 180: 425-442.

25. Agarwal B (2010) Does Women's Proportional Strength Affect Their Participation? Governing Local Forests in South Asia. World Development 38(1): 98-112.

26. Hartter, Joel (2010) Resource Use and Ecosystem Services in a Forest Park Landscape. Society and Natural Resources 23(3): 207-223.

27. Voeks, Robert (2007) Are Women Reservoirs of Traditional Plant Knowledge? Gender, Ethnobotany and Globalization in Northeast Brazil. Singapore Journal of Tropical Geography 28(1): 7-20.

28. Tindall DB, Davies S, Mauboules C (2003) Activism and Conservation Behavior in an Environmental Movement: The Contradictory Effects of Gender. Society \& Natural Resources 16(10): 909-932.

29. Ozanne LK, Humphrey CR, Smith PM (1999) Gender, Environmentalism, and Interest in Forest Certification: Mohai's Paradox Revisited. Society \& Natural Resources 12(6): 613-622.

30. Smith, William James, Zhongwei Liu, Ahmed Saleh Safi, Karletta Chief (2014) Climate Change Perception, Observation and Policy Support in Rural Nevada: A Comparative Analysis of Native Americans, Nonnative Ranchers and Farmers and Mainstream America. Environmental Science and Policy 42: 101-122.

31. Lobao L, Rogelio Saenz (2002) Spatial Inequality and Diversity as an Emerging Research Area. Rural Sociology 67(4): 497-513.

32. Kiker BF (1966) The Historical Roots of the Concept of Human Capital. Journal of Political Economy 74(5): 481-499.

33. Coleman, James S (1988) Social Capital in the Creation of Human Capital. American Journal of Sociology 94: S95-S120.

34. Putnam Robert D (2000) Bowling Alone: The Collapse and Revival of American Community. Simon \& Schuster, New York, USA.

35. Fulkerson, Gregory M, Gretchen H, Thompson (2008) Fifteen Years of Social Capital: Definitional Analysis of Journal Articles 1988-2003. Sociological Inquiry 78: 536-557.

36. Wilson, William Julius (1987) The Truly Disadvantaged: The Inner City, the Underclass, and Public Policy. Chicago, University of Chicago Press, USA.
37. Wilson, William Julius (1996) When Work Disappears: The World of the New Urban Poor, New York, USA.

38. Wimberley, Ronald, Libby Morris (2002) The Legitimization of Poverty: Assistance for the Black Belt South. Southern Rural Sociology 294-306.

39. Lobao L (1996) A Sociology of the Periphery Versus a Peripheral Sociology: Rural Sociology and the Dimension of Space. Rural Sociology 61(1): 77-102.

40. Gieryn T (2000) A Space for Place in Sociology. Annual Review of Sociology 26: 463-496.

41. Tickamyer A, Cynthia Duncan (1990) Poverty and Opportunity Structure in Rural America. Annual Review of Sociology 16: 67-86.

42. Castells, Manuel (2010) The Rise Of Network Society. ( $2^{\text {nd }}$ edn), WileyBlack well\&Sons, West Sussexm, United Kingdom.

43. Reed, John Shelton (1993) Surveying the South: Studies in Regional Sociology. Columbia, University of Missouri Press, USA.

44. Duncan C (1996) Understanding Persistent Poverty: Social Class Context in Rural Communities. Rural Sociology 61(1): 103-124.

45. Tickamyer A (2000) Space Matters! Spatial Inequality in Future Sociology. Contemporary Sociology 29(6): 805-813.

46. Fisher, Dana R (2001) Resource Dependency and Rural Poverty: Rural Areas in the United States and Japan. Rural Sociology 66(2): 181-202.

47. Mencken F, Carson (1998) Persistent Differences in Well-being Between Appalachian Subregions. Growth and Change 29(4): 469-479.

48. Friedman, Samantah, Daniel Lichter (1998) Spatial Inequality and Poverty Among American Children. Population Research and Policy Review 17(2): 91-109.

49. Lee MA, Mark Harvey, Allison Neustrom (2002) Local Labor Markets and Caseload Decline in Louisiana in the 1990. Rural Sociology 67(4): 556-577.

50. Garson David G (2013) Hierarchical Linear Modeling: Guide and Applications. Thousand Oaks, Sage, USA.

51. Neumayer, Eric (2010) Weak versus Strong Sustainability: Exploring the Limits of Two Opposing Paradigms. ( ${ }^{\text {rd }}$ edn), Cheltenham, Edward Elgar, UK.

52. Solow RM (1993) An Almost Practical Step towards Sustainability. Resources Policy 16: 162-72.

53. Hartwick JM (1977) Intergenerational Equity and the Investing of Rents from Exhaustible Resources. American Economic Reviews 67(5): 972-974.

54. Butler, Brett J (2008) Family Forest Owners of the United States, 2006. Newton Square, US Department of Agriculture, Forest Service, Northern Resource Station.

55. Bourdie P (1986) The Forms of Capital. In John Richardson (Ed.), Handbook of Theory and Research for the Sociology of Education. Greenwood, New York, USA, pp. 241-258.

56. Butler, Brett J, Zhao Ma (2011) Family Forest Owner Trends in the Northern United States. Northern Journalof Applied Forestry 28(1): 13-18.

57. Brundtland Commission (1987) Our Common Future. Report of the World Commission on Environment and Development. New York, USA. 
This work is licensed under Creative Commons Attribution 4.0 License DOI: $10.19080 /$ ARTOAJ.2017.04.555630

\section{Your next submission with Juniper Publishers} will reach you the below assets

- Quality Editorial service

- Swift Peer Review

- Reprints availability

- E-prints Service

- Manuscript Podcast for convenient understanding

- Global attainment for your research

- Manuscript accessibility in different formats ( Pdf, E-pub, Full Text, Audio)

- Unceasing customer service

Track the below URL for one-step submission https://juniperpublishers.com/online-submission.php 